総 説

\title{
我が国のクリティカルケア看護領域における 臨床判断に関する文献レビュー
}

A Review of Literature on Clinical Judgment in Critical Care Nursing in Japan

\author{
江口秀子 ${ }^{11}$ 明石惠子² \\ Hideko Eguchi Keiko Akashi
}

\begin{abstract}
本研究の目的は, 文献しビューを通してクリティカルケア看護領域における「臨床判断」の特徵を明 らかにすることである. 医学中央雑誌WEB 版を用い臨床判断に関する国内の文献を検索した結果, ワリティカルケア看護領域での臨床判断に関する研究は 2005 年以降からみられ, 2012 年 4 月までに 発表された 8 文献を分析対象とした. 結果, 《見通しを立てる局面》《見通しを確定し，ケアを選択す る局面》《ケアを実施しながら判断する局面》〈振り返り, 経験の蓄えとする局面》の 4 つの局面が見出 された. さらに臨床判断を構成する要素は, (1)臨床判断の内容, (2)臨床判断に用いる情報・手がかり, (3)臨床判断に影響を及ぼす要因に分類された. そして, クリティカルケア看護領域の臨床判断の特徵 は, 疾患や生体情報, 患者の症状とその経時的变化という客観的情報が重要視されていることと, 過 去の類似した事例の経験の有無が臨床判断に影響を及ぼしていることであった。
\end{abstract}

キーワード : クリティカルケア, 臨床判断, 看護師

Key words : critical care, clinical judgment, nurse

\section{I . はじめに}

医療の高度化，複雑化が進み，看護師には質の高い 看護の提供が求められている. 特にクリティカルケア 看護領域においては, チーム医療の推進に伴い, 看護 師の役割拡大が進む中で，他職種と協働しながら専門 性の高い臨床実践能力を発揮することが必要とされて いる，そして，高度先進医療が展開され，様々な治療 が複合して行われる中で, 複雑かつ重症化した患者の 全身管理を中心とした看護においては，短時間で集中 的な臨床判断が求められる.

Benner, P. ${ }^{1)}$ は，過ちが許されない生命の危機的状 況下では，迅速な判断と対応が求められ，そのような 優れた専門技能を身につけるには，切迫した状態の中 での経験的学習と行動しつつ考えること(thinking-inaction：状況が変わっていく中で, 行動しながら考え ていくこと)が求められると述べている.さらに， あ いまいで予測のつかない状況や当然と思われる場面で 予想と明らかに異なる場合には, 思考と判断を働かせ る必要がある. そのため, クリティカルケアで最も必 要とされる能力は, 問題を早い段階で正確に把握する ことであり, 臨床判断こそが救命技術の一つであると 語っている.これらのことから, クリティカルケア看 護領域の看護師が専門性を発揮し, 自立して質の高い 看護を提供するためには, 主体的な臨床判断能力が必 要となる.

Corcoran ${ }^{2)}$ は「クリニカル・ジャッジメントは患者ケ アについて決定を下すことである，それには，認知的 な熟考および直観的な過程が関与する．適切な患者の

受付日: 2013 年 7 月 1 日 受理日 : 2013 年 12 月 4 日

${ }^{1)}$ 名古屋市立大学大学院看護学研究科博士後期課程 ${ }^{2}$ ) 名古屋市立大学看護学部 
データ，臨床的な知識及び状況に関する情報が考慮さ れる」と定義し, さらに Tanner ${ }^{3}$ は, 臨床判断はすべ ての医療専門職にとって不可欠な技術としている. 我 が国においても, 看護師の臨床判断は実践能力の重要 な一部として，様々な領域での看護研究がみられる. これまでの臨床判断に関する研究では, 臨床判断の構 成要素や臨床経験年数による臨床判断能力の差異, 臨 床判断のプロセスやパターン, 臨床判断の内容, 臨床 判断の根拠, 臨床判断に影響を及ぼす因子などが明ら かにされてきた ${ }^{4,5)}$.これらの臨床判断の研究をもと にクリティカルケア看護領域の「臨床判断」の特徵を明 らかにすることは, クリティカルケア看護師の専門性 を踏まえた臨床判断能力育成の方略を考えるための示 唆を得ることができると考える.

\section{II. 研究目的}

文献レビューを通してこれまでの臨床判断に関する 研究の動向を探りながら, クリティカルケア看護領域 における「臨床判断」に関する研究論文について概観 し, クリティカルケア看護領域における「臨床判断」の 特徴を明らかにする。

\section{III. 研究方法}

\section{1. 対象文献の選定}

\section{1) 第一段階}

国により看護師の役割や他職種との関係性には相違 があり, 臨床判断の内容や実践内容に影響を及ぼして いると考えられるので, 対象は国内文献のみとした.

医学中央雑誌 WEB 版を用いて, 国内の文献検索を 行った．期間はWEB 版での検索が可能な 1983 年〜 2012 年 4 月末までのものとした. キーワードとして, 「看護」「臨床判断」(臨床判断能力, 臨床判断尺度, 臨 床判断力)を入力し，「原著論文」と限定した結果， 95 文献が抽出された。

これらの文献のうち, (1)看護系学会誌, (2)大学・短 期大学の紀要, (3)看護系雑誌のいずれかに掲載され, 研究の体裁を整えた論文を対象とした。 その結果, 対 象となる文献は 38 件であった. このうち 3 件は文献 レビューであったため, 今回の対象から除外した. さ らに, 臨床場面での看護師の臨床判断を研究目的とす るため, 看護学生を研究対象とした 2 件も除外した.
残った 33 件の文献の背景を最初に分析した.

\section{2 ）第二段階}

本研究はクリティカルケア看護領域における臨床判 断の特徵を明らかにすることを目的にしているため, 収集した 33 文献を概観し, 救急・ICU, 周手術期看 護領域の看護師の臨床判断が記述された文献をクリ ティカルケア看護領域における臨床判断の研究論文と した. その結果, 8 件の文献 ${ }^{(13)}$ を今回の分析対象と した.

\section{2. 分析方法}

分析では, まず選定した対象文献を精読し, 文献ご とに「論文タイトル」「発行年」「研究年」「研究部署」「研 究目的」「研究方法とデー夕収集方法」「対象者と人数」 「臨床判断の定義とその背景」「研究結果」を抽出し, そ の概要を整理した。そして文献ごとに「臨床判断とし て何を明らかにしているのか」という視点で結果を読 み込み，その内容を抽出しデー夕とした，それぞれの データの共通性や相違点を比較検討し, 各文献が示し ている知見を集積し, 類似性に従って分類した. 次に 対象文献の研究結果をもとに意味内容の共通するもの をグループ化し簡単な言葉や文章に置き換えた.

なお, 文献内容の解釈, デー夕の分類に際しては, 文献を読み込み, 記述内容の意味を変えないように努 めた。 さらに研究過程で何度も共同研究者間で内容の 解釈, データの分類を検討し, 信頼性を確保した.

\section{IV. 結果}

\section{1.「臨床判断」に関する国内の研究の動向}

1983 年までさかのぼって「臨床判断」に関する文献 を検索した結果, 我が国における臨床判断をテーマに した最初の研究論文は, 1989 年に発表された佐藤の 「看護婦の臨床判断の『構成要素と段階』と院内教育へ の提言」 ${ }^{14)}$ であった．その後 10 数年間は発表された論 文は少なく, 2005 年以降に増加し, 毎年, 複数の論 文が発表されている(図 1). また, 研究対象となった 看護師の所属は, 精神科領域が最も多く 8 件, 次いで 救急・ICU 領域 が 4 件, 周手術期領域が 4 件であっ た(表 1).

クリティカルケア看護領域の「臨床判断」に関する最 初の論文は 2005 年の杉本ら ${ }^{13)}$ の外科系病棟に勤務す る看護師を対象とした『異常を察知した看護師の臨床 
件

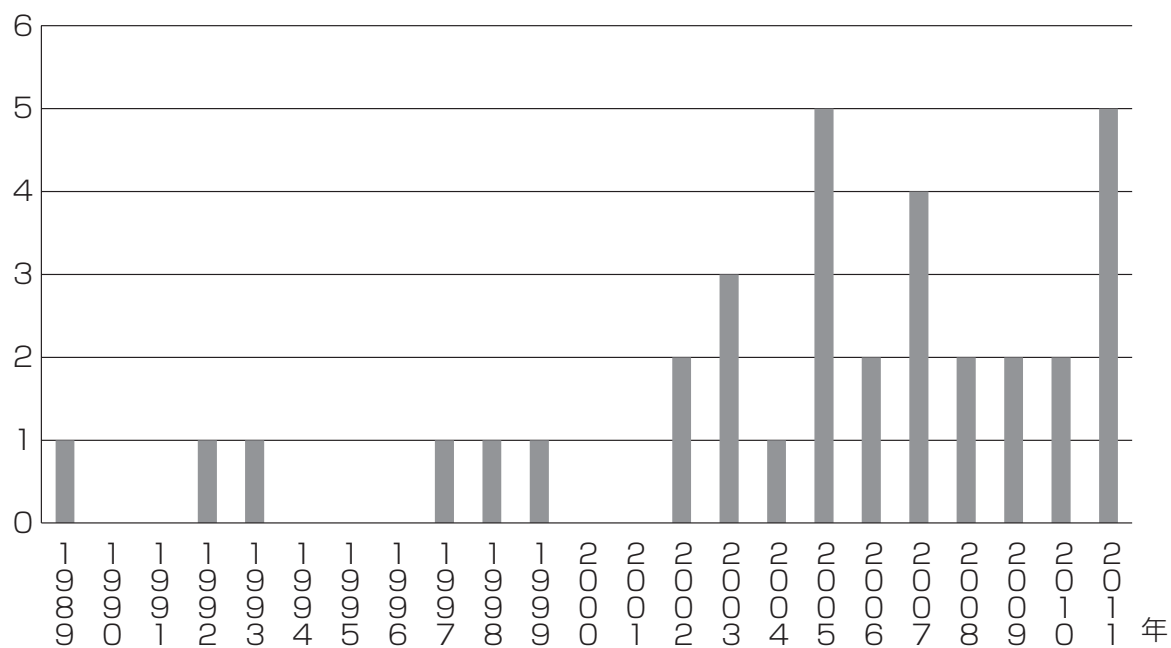

\begin{tabular}{|l|r|}
\hline \multicolumn{1}{|c|}{ 対象者の所属 } & 件数 \\
\hline \hline 精神科 & 8 \\
\hline 救急・ICU & 4 \\
\hline 周手術期 & 4 \\
\hline 在宅・訪問 & 2 \\
\hline 老年 & 1 \\
\hline 小児 & 1 \\
\hline その他 & 13 \\
\hline \hline 計 & 33 \\
\hline
\end{tabular}

判断の分析』と岩田 ${ }^{12)}$ の ICU 看護師を対象とした 『異常を判断した ICU 看護師の思考パターンの分析』 である.クリティカルケア看護領域における臨床判断 に関する研究は比較的最近になってからといえる。

以下に，クリティカルケア看護領域における臨床判 断の研究の概要と対象論文の研究結果の内容について 述べる。

\section{2. クリティカルケア看護領域における臨床判断の研 究の概要 (表 2)}

\section{1 ）用語の定義}

「臨床判断」の用語の定義を論文中で明確に示したも のは 6 件であった．臨床判断の定義として, Corcoran の定義である「適切な患者データ, 臨床知識および状 況に関する情報から，認知的な熟考や直観によって， 患者ケアについて決定を下すことである」 ${ }^{3)}$ や Tanner の定義「看護師がクライエントとの関係性において行 う一連の決定である」 ${ }^{15)} 引$ 引，もしくはそれらを基 盤とした定義が複数の文献で用いられている.さらに Benner の「看護師が対象の状況について時間を追って 観察し，その状況の変化を通して理解した内容」 ${ }^{16)}$ 用いている文献もみられる。 また，用語の定義として の明確な記述はない 2 件も，論文中で臨床判断の説明 をしている箇所から，背景に Corcoran の定義もしく は Tannerの定義が用いられていることが推測された.

\section{2 ) 研究方法}

研究デザインは, 8 件中 7 件が質的研究で, 1 件の
みアクションリサーチであった。 質的研究のデータ収 集方法は, 参加観察法と半構成的面接法の組み合わせ が 3 件, 半構成的面接法のみが 1 件, グループインタ ビューが 3 件であった. 7 件の質的研究が題材にした 場面は，特定の看護場面での判断をとらえたものが 4 件 ${ }^{6,11 ~ 13)}$ 対象とする患者を特定し，その患者との関わ りの中から判断場面を抽出したものが 3 件 $^{7 \sim 9)}$ であっ た.

\section{3. 対象論文の研究結果の内容}

分析対象とした 8 文献の研究結果から臨床判断につ いて明らかにされた内容を帰納的に整理・分類した結 果，1）臨床判断の局面に関すること，2）臨床判断の 構成要素に関わることに分類された. 臨床判断の構成 要素は，さらに(1)臨床判断の内容に関するもの，(2)臨 床判断に用いた情報・手がかりに関するもの, (3)臨床 判断に影響を及ぼす要因に関するものの 3 つに分類さ れた.

臨床判断の局面と構成要素の関連については図 2 に示し，それぞれの内容を以下に述べる。

\section{1) 臨床判断の局面}

臨床判断の局面を明らかにした文献は 4 文 献, ${ }^{6,9,11)}$ で, 内容が共通しているものをグループ化し, グループを示す表題を付けた．表題を《》で，その内 容を説明するデータをく〉で示した.

臨床判断の局面については，これまでの情報と経験 から《見通しを立てる局面》, 現在の状況から《見通し 


\section{表 2 選択された研究論文の概要}

\begin{tabular}{|c|c|c|c|c|}
\hline & 1 & 2 & 3 & 4 \\
\hline 論文タイトル & $\begin{array}{l}\text { 開腹術後患者の早期離床ケア } \\
\text { 場面における看護師の臨床判 } \\
\text { 断 }\end{array}$ & \begin{tabular}{|l|} 
周手術期患者に対する病棟看 \\
護師の臨床判断
\end{tabular} & $\begin{array}{l}\text { 急性呼吸不全患者への非侵襲 } \\
\text { 的陽圧換気療法(NPPV) 継続 } \\
\text { のための看護師の臨床判断に } \\
\text { 関する研究 }\end{array}$ & $\begin{array}{l}\text { 心臓手術患者の看護における } \\
\text { 臨床判断 }\end{array}$ \\
\hline 論文発表年 & 2011 年 & 2011 年 & 2011 年 & 2009 年 \\
\hline $\begin{array}{l}\text { 研究の行わ } \\
\text { れた年 }\end{array}$ & 2006 年 & 2008 年 & 2009 年 & 2007 年 \\
\hline $\begin{array}{l}\text { 研究を行った } \\
\text { 部署 }\end{array}$ & $\begin{array}{l}\text { 医科大学付属病院の消化器外 } \\
\text { 科病棟 }\end{array}$ & $\begin{array}{l}2 \text { 施設の周手術期の成人患者 } \\
\text { を対象とする病棟 }\end{array}$ & $\begin{array}{l}\text { 急性呼吸不全患者に対して集 } \\
\text { 中治療室あるいは呼吸器内科 } \\
\text { 病棟で NPPVを常に 3〜 5台 / } \\
\text { 日使用している総合病院 }\end{array}$ & 3 県 4 施設の心臓外科病棟 \\
\hline 研究目的 & $\begin{array}{l}\text { 開腹術後患者の早期離床ヶア } \\
\text { 場面における看護師の臨床判 } \\
\text { 断を明らかにする }\end{array}$ & $\begin{array}{l}\text { 周手術期患者に対する病棟看 } \\
\text { 護師の臨床判断を明らかにす } \\
\text { る }\end{array}$ & $\begin{array}{l}\text { 急性呼吸不全患者がNPPV を } \\
\text { 継続していくために, 看護師 } \\
\text { が行っている臨床判断を明ら } \\
\text { かにする }\end{array}$ & $\begin{array}{l}\text { 心臟手術患者の看護における } \\
\text { 臨床判断を明らかにする }\end{array}$ \\
\hline 研究方法 & $\begin{array}{l}\text { 帰納的分析方法を用いた質的 } \\
\text { 研究 }\end{array}$ & $\begin{array}{l}\text { 帰納的分析方法を用いた質的 } \\
\text { 研究 }\end{array}$ & $\begin{array}{l}\text { 修正版ブラウンデッド・セオ } \\
\text { リー・・プローチを用いた質 } \\
\text { 的研究 }\end{array}$ & $\begin{array}{l}\text { 帰納的分析方法を用いた因子 } \\
\text { 探求型研究 }\end{array}$ \\
\hline $\begin{array}{l}\text { データ収集 } \\
\text { 方法 }\end{array}$ & 参加観察, 半構成的面接 & 小ブループインタビュー & 参加観察, 半構成的面接 & 半構成的面接 \\
\hline 研究対象者 & \begin{tabular}{|l|} 
開腹術後の患者へのケアを直 \\
接行っている看護師 9 名
\end{tabular} & \begin{tabular}{|l|} 
直接看護ヶアを行っている看 \\
護師 20 名
\end{tabular} & $\begin{array}{l}\text { NPPV 装着患者へのケアに携 } \\
\text { わってから } 1 \text { 年以上の経験が } \\
\text { ある看護師 } 14 \text { 名 }\end{array}$ & $\begin{array}{l}\text { 心臓手術患者の看護における } \\
\text { 臨床経験 } 5 \text { 年目以上の看護師 } \\
8 \text { 名 }\end{array}$ \\
\hline $\begin{array}{l}\text { 臨床判断の } \\
\text { 用語の定義 }\end{array}$ & $\begin{array}{l}\text { 看護師が行う患者ケアについ } \\
\text { ての決定. 看護師が判断した } \\
\text { 内容, 判断に用いた情報, 判 } \\
\text { 断への影響要因からなり, 実 } \\
\text { 際の行動までを含む }\end{array}$ & $\begin{array}{l}\text { 看護師が患者ケアについて行 } \\
\text { う一連の決定であり, 実践も } \\
\text { 含む }\end{array}$ & $\begin{array}{l}\text { 看護師が患者のデータや臨床 } \\
\text { 的な知識, 状況に関する情報 } \\
\text { を考慮し, 直観や熟考を含ん } \\
\text { だ決意, 決定をすることおよ } \\
\text { びそのプロセス }\end{array}$ & $\begin{array}{l}\text { 看護師が (心臓手術患者の看 } \\
\text { 護にあたって), 科学的知識 } \\
\text { や実践的知識を基に分析的思 } \\
\text { 考や直観を働かせながら, 状 } \\
\text { 況の認知をし, ケアの味味を } \\
\text { 行いながらケアの決定をする } \\
\text { こと }\end{array}$ \\
\hline $\begin{array}{l}\text { 背景にある } \\
\text { 定義 }\end{array}$ & Tanner の定義 & Tanner の定義 & Corcoran の定義 & Corcoran の定義 \\
\hline
\end{tabular}




\begin{tabular}{|c|c|c|c|c|}
\hline & 5 & 6 & 7 & 8 \\
\hline 論文タイトル & $\begin{array}{l}\text { 臨床判断能力の向上に向けた } \\
\text { 「暗默知」伝授の一方略 }\end{array}$ & $\begin{array}{l}\text { 看護師の緊急性の判断に関す } \\
\text { る研究－初期〜三次対応の救 } \\
\text { 急外来において- }\end{array}$ & $\begin{array}{l}\text { 異常を判断した ICU 看護師の } \\
\text { 思考パターンの分析 }\end{array}$ & $\begin{array}{l}\text { 異常を察知した看護師の臨床 } \\
\text { 判断の分析 }\end{array}$ \\
\hline 論文発表年 & 2007 年 & 2006 年 & 2005 年 & 2005 年 \\
\hline $\begin{array}{l}\text { 研究の行わ } \\
\text { れた年 }\end{array}$ & 2004 年〜2005 年 & 2003 年 & 記載なし & 記載なし \\
\hline $\begin{array}{l}\text { 研究を行った } \\
\text { 部署 }\end{array}$ & $\begin{array}{l}\text { 北米型 ER を実践している病 } \\
\text { 院併設型救命救急センター }\end{array}$ & $\begin{array}{l}2 \text { 県 } 3 \text { 総合病院の初期 三次 } \\
\text { 対応の救急外来 }\end{array}$ & 医学部付属病院の ICU 病棟 & $\begin{array}{l}\text { 医学部付属病院の消化器およ } \\
\text { び乳腺内分泌疾患患者の外科 } \\
\text { 的治療を行う病棟 }\end{array}$ \\
\hline 研究目的 & $\begin{array}{l}\text { 1. ER 看護師チームの臨床判 } \\
\text { 断能力の向上を果たすために } \\
\text { 有 用な方 略を開 発 する. } \\
\text { 2. 上記 } 1 \text { に基づくアワショ } \\
\text { ンプランの評価から, ER 看 } \\
\text { 護師の臨床判断の種類と判断 } \\
\text { に至る手がかりを明らかにす } \\
\text { る }\end{array}$ & $\begin{array}{l}\text { 初期〜三次対応の救急外来に } \\
\text { おける看護師の実践活動から } \\
\text { 看護師の緊急性に対する臨床 } \\
\text { 判断の構造と過程を明らかに } \\
\text { する }\end{array}$ & $\begin{array}{l}\text { ICU 看護師が異常を判断する } \\
\text { までの思考プロセスを明らか } \\
\text { にする }\end{array}$ & $\begin{array}{l}\text { 患者の異常を察知した時に, } \\
\text { 看護師が捉えた事象と臨床判 } \\
\text { 断の特徵を明らかにする }\end{array}$ \\
\hline 研究方法 & アクションリサーチ法 & $\begin{array}{l}\text { 帰納的分析方法を用いた質的 } \\
\text { 研究 }\end{array}$ & $\begin{array}{l}\text { Berelson の内容分析に基づい } \\
\text { た質的研究 }\end{array}$ & $\begin{array}{l}\text { Berelson の内容分析に基づい } \\
\text { た質的研究 }\end{array}$ \\
\hline $\begin{array}{l}\text { データ収集 } \\
\text { 方法 }\end{array}$ & カンファレンス記録 & 参加観察, 半構成的面接 & 小ブループインタビュー & 小ブループインタビュー \\
\hline 研究対象者 & $\begin{array}{l}\text { 救命救急センターER 部門に } \\
\text { 勤務する看護師 } 23 \text { 名 }\end{array}$ & $\begin{array}{l}\text { 初期〜三次対応の救急外来に } \\
\text { 勤務する看護師 } 22 \text { 名 }\end{array}$ & ICU 看護師 21 名 & $\begin{array}{l}\text { 外科系病棟に勤務する看護師 } \\
15 \text { 名 }\end{array}$ \\
\hline $\begin{array}{l}\text { 臨床判断の } \\
\text { 用語の定義 }\end{array}$ & $\begin{array}{l}\text { 看護師がある手がかりから, } \\
\text { 成り行きを推測し, 意図的な } \\
\text { 介入を開始するに至る思考過 } \\
\text { 程 }\end{array}$ & $\begin{array}{l}\text { 臨床の現場で看護師が患者の } \\
\text { ケアについて看護判断を下す } \\
\text { こと. それには, 認知的な熟 } \\
\text { 考および直観的な過程が関与 } \\
\text { する }\end{array}$ & $\begin{array}{l}\text { 用語の定義の記述はない } \\
\text { *さまざまなデータの分析と } \\
\text { * 統合によって患者情報や看護 } \\
\text { 場面を解釈し, 現在の状態や } \\
\text { 起こりうる危険性を診断し, } \\
\text { 看護活動を決定すること }\end{array}$ & $\begin{array}{l}\text { 用語の定義の記述はない } \\
\text { *臨床判断は, 分析的思考に } \\
\text { よる分析的判断, 非分析的な } \\
\text { 直観的判断と説話的判断の } 3 \\
\text { つに分類される }\end{array}$ \\
\hline $\begin{array}{l}\text { 背景にある } \\
\text { 定義 }\end{array}$ & Benner の定義 & Corcoran の定義 & Corcoran の定義 & Tanner の定義 \\
\hline
\end{tabular}

*は用語の定義としての明確な記述はないが，論文中で臨床判断の説明をしている箇所を抜粋 


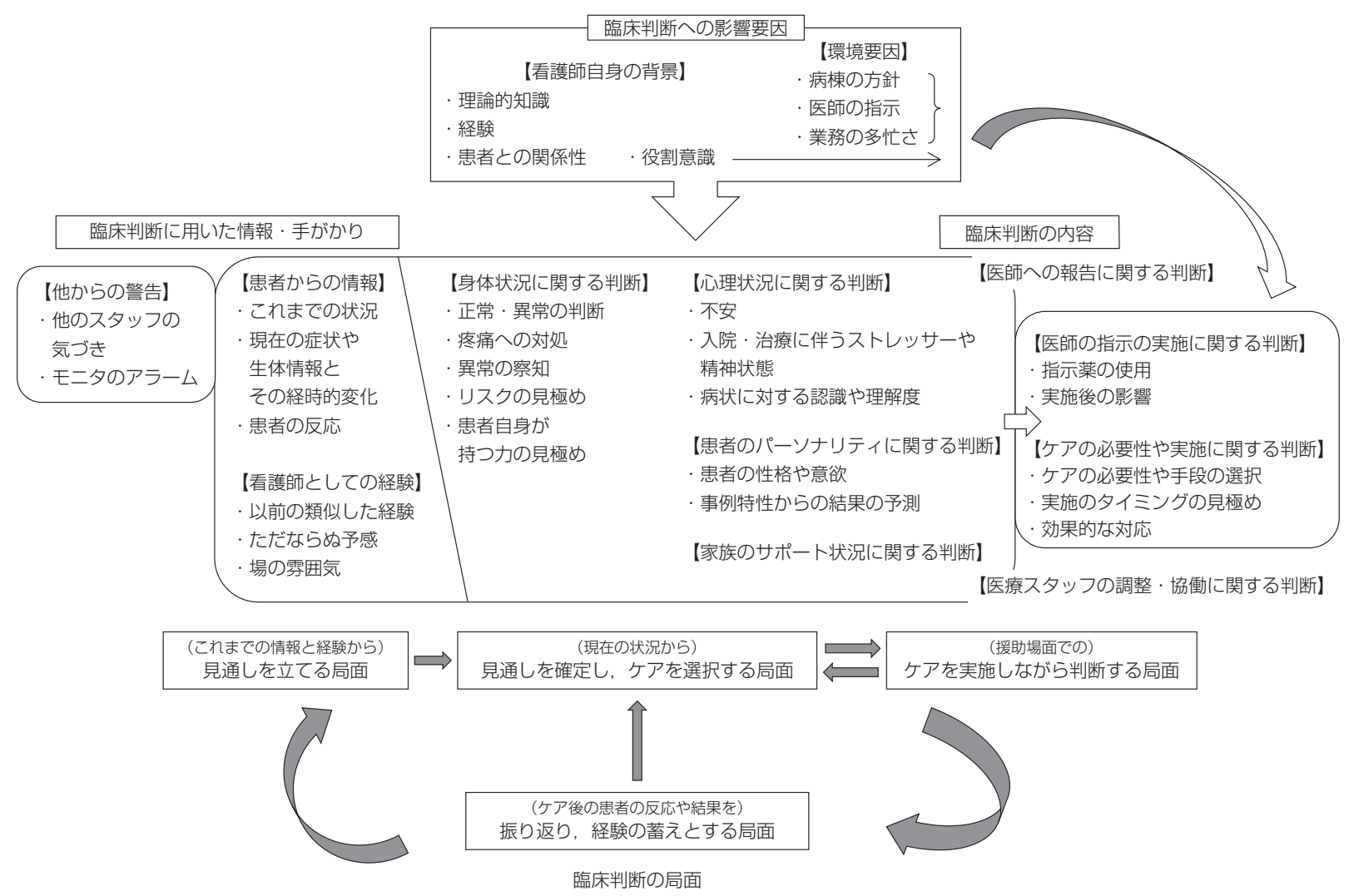

図 2 クリティカルケア看護領域における看護師の臨床判断の要素の関連性

を確定し，ケアを選択する局面》，援助場面での《ケア を実施しながら判断する局面》, ケア後の患者の反応 や結果を《振り返り，経験の蓄えとする局面》の 4 つの 局面が見出された。《見通しを立てる局面》とは，直前 勤務看護師からの報告や検査データなどの事前情報と 看護師の経験から〈状況の認知〉をし，〈予測〉を立てる ことである.《見通しを確定し，ケアを選択する局面》 とは，直接患者と関わり，現在の状況から《見通しを 立てる局面》での予測に基づき，〈焦点化〉・〈絞込み〉 による〈要因の重点査定〉を行い, 予測が〈確信〉に移行 する過程の中で〈ケアの方向性を定め〉，〈ケアの効果 の見定め〉をすることである.《ケアを実施しながら判 断する局面》とは，選択したケアを実施する中で，患 者の反応を見ながら実施方法を修正するなど〈働きか けながら臨床判断〉を行い, ケアの効果の評価を行う ことである，そのため《見通しを確定し，ケアを選択 する局面》と《ケアを実施しながら判断する局面》は双 方向に関わっていた。 そして, 《振り返り, 経験の蓄 えとする局面〉とは，ケア後の患者の反応や結果を〈振
り返り〉，ケアの効果に対する判断を行い，〈経験の蓄 え〉としていく過程である. 一連のプロセスを振り返 ることが経験の蓄積につながり, 《見通しを立てる局 面》や《見通しを確定し，ケアを選択する局面》への影 響要因となっていた。

\section{2 ) 臨床判断の構成要素}

3 つに分類された臨床判断を構成している要素をそ れぞれ説明する.【【はカテゴリー，『』はその下位 のカテゴリーを示している.

(1) 臨床判断の内容

臨床判断の内容を示すのは, 5 文献 $7,8,10,11,13)$ であっ た。

臨床判断の内容としては, 患者に関する判断として, 【身体状況に関する判断】心理状況に関する判断】患 者のパーソナリティに関する判断】家族のサポート状 況に関する判断】, 看護行為の実施に関する判断とし て【医師の指示の実施に関する判断】ケアの必要性や 実施に関する判断】，さらに[医師への報告に関する判 断】と場の状況を判断する【医療スタッフの調整・協働 
に関する判断】の 8 カテゴリーが生成された.

【身体状況に関する判断】では，バイタルサインをは じめとするモニタリングされた值や患者の訴えをもと に，『正常・異常の判断』『疼痛への対処』をし，『異常 の察知』や『リスクの見極め』をするだけでなく，『患者 自身が持つ力を見極め』て，ケア方法を選択するため の判断指標の一つにしていた.【心理状況に関する判 断】では，術前の『不安』や『入院・治療に伴うストレッ サーや精神状態』を査定し, 『病状に対する認識や理解 度』を確認しながらそれぞれへの対処法を判断してい た.【患者のパーソナリティに関する判断】は，『患者 の性格や意欲』から働きかけの方法を判断し，『事例の 特性から結果を予測』することである。【家族のサポー 卜状況に関する判断】は，家族関係や面会の状況から 家族のサポート状況を判断することである.

【医師の指示の実施に関する判断】は，『指示薬の使 用』に関する判断であり，看護師は指示薬であっても 実際の使用や使用方法については，その都度患者の状 況をアセスメントし，状況に応じては医師に報告し， 新たな薬剈の指示を確認していた。また睡眠薬の投与 については転倒のリスクと関連させながら『実施後の 影響』について推測し，使用の有無やタイミングを判 断していた.

【ケアの必要性や実施に関する判断】は，『ケアの必 要性や手段の選択』，『実施の夕イミングの見極め』に よって『効果的な対応』をするための判断であり，【身 体状況に関する判断】心理状況に関する判断】患者の パーソナリティに関する判断】に引き続いて行われる 判断である.

【医師への報告に関する判断】は，【身体状況に関す る判断】の結果などを医師に報告するタイミングにつ いての判断である.【医療スタッフの調整・協働に関 する判断】は，状況に応じた医療チーム，看護チーム の編成のために用いられる臨床判断であり, クリティ カルな状況に応じて適切な治療・ケアが迅速に行われ るために必要な判断であった.

（2）臨床判断に用いた情報・手がかり

臨床判断に用いた情報・手がかりを示すのは，5文 献, 10 13)であった.

用いた情報・手がかりは，【患者からの情報】看護 師としての経験】他からの警告】の 3 つのカテゴリー に分類された.

【患者からの情報】とは，疾患や治療に伴うこれまで
の経過やケアの進渉状況などの『これまでの状況』と， 現在の症状や訴え, バイタルサインや検査データなど の客観的デー夕と短時間内での経時的変化を示す『現 在の症状や生体情報とその経時的変化』, そして患者 の行為や表情，顔色，言葉から読み取った，異常な眠 気や反応の鈍さ，活動の低下，つじつまの合わない会 話などの『患者の反応』，さらに患者自身の性格や活 気・意欲を示す『患者のパーソナリティ』である。

【看護師としての経験】とは，これまでに経験した類 似した反応のパターンの認知によって異常や回復を判 断する『以前の類似した経験』や，今までとは違うとい う感覚や患者の言動と観察デー夕の不一致からくる 『ただならぬ予感』, その場の状況から判断する『場の 雲囲気』などで，看護師のこれまでの経験に基づいた 感覚で表現されていた。

【他からの警告】とは, 異常を判断するきっかけと なった時の『他のスタッフの気づき』や『モニタのア ラーム』を示し，経験の浅い看護師の特徵の一つでも あった

（3）臨床判断への影響要因

影響要因を明らかにしているのは，1 文献6)のみで あった。影響要因は【環境要因】と【看護師自身の背景 要因】に分けられ,【環境要因】としては,『病棟の方針』, 『医師の指示』，『業務の多忙さ』が示されていた。【看 護師自身の背景要因】としては,『理論的知識』,『経験』, 看護師としての『役割意識』,『患者との関係性』が挙げ られている.

『病棟の方針』, 『医師の指示』, 『業務の多忙さ』, 看 護師の『役割意識』は，ケアの実施を判断する場面での 影響要因となっており, 看護師の『理論的知識』『経験』 は，患者の身体状況や心理状況，ケアの必要性や方法 を判断する場合の影響要因となっていた。『患者との 関係性』は, これまでの対象者との関わりの頻度によっ てその対象者に対する情報量が変化することであり， 情報量の変化が判断に影響していた。

\section{V. 考察}

\section{1. クリティカルケア看護における臨床判断の特徵}

1990 年に雑誌「看護研究」で Corcoran の『Clinical

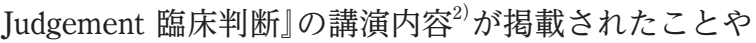
1992 年に Benner, $\mathrm{P}^{17)}$ のベナー看護論でエキスパート ナースの臨床能力の卓越性が紹介されて以来，我が国 
においても看護師の臨床判断に関する研究が少しずつ みられてきたが, クリティカルケア看護領域における 看護師の「臨床判断」に関する研究の歴史はまだ浅い. それは，我が国において ICUが広まったのが 1980 年 代になってからであり, それと並行して日本救急医学 会看護部会や日本集中治療学会看護部会が発足し, 救 急看護，ICU 看護の専門性の確立をめざして学問的な 追及がスタートしたという歴史的背景も関連している と考えられる.

クリティカルケア看護師は短時間で集中的に臨床判 断を求められるが，その中で異常を予測・察知すると いう緊急性の判断, 症状緩和のための薬剤投与やケア の実施, 回復を促進するためのケアの工夫や実施の夕 イミング・方法に関する判断を行っていた. つまり, クリティカルケア看護領域における臨床判断には, 異 常の察知やリスクの見極め, 危険性を回避するという 生命に関する判断と, 苦痛症状の緩和や回復促進のた めのケアの選択という対象者の安楽と生活を支えるた めの判断という 2 つの側面がある.

臨床判断の研究において初期からの取り組みが多 かった精神科看護領域では, 患者の暴力という危険性 を察知する場面や行動制限のある(保護室入室) 患者に

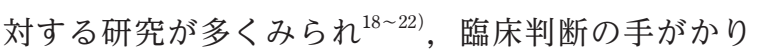
は, 表情, 眼つき・視線, 声, コミュニケーションの 状態, 行動といった患者の示す言動であり, それまで の患者の状態との比較や看護師の行為に対する反応が 重要視されていた。 つまり, それらを用いて患者の精 神状態の変化や行動を予測することが重要な臨床判断 の一つとされている. Tanner は, 「臨床判断は看護師 がクライエントとの関係性において行う一連の決定で ある $\rfloor^{15)}$ 述べているが, 特に精神科看護領域では, 看 護師と患者が関わる期間が比較的長いため, それまで の看護師と患者の関係性が判断の手がかりにもなり, 判断への影響要因にもなっていると考えられる.

一方，クリティカルケア看護領域においては患者と の関係性を構築する時間が短く, 患者のパーソナリ ティや家族との関係性に関する情報は乏しい，特に救 急看護の場面では，それまでの患者情報がそしく，患 者と関わる時間も短い，そのため，患者との関係性よ りも最初の出会いでの印象と予測が大きな位置を占 め, その後の生命予後に与える影響も大きい. よって, 疾患, 生体情報, さらに疼痛などの症状とそれらの経 時的変化という客観的情報を用いた臨床判断が重要視
される.これがクリティカルケア看護師の臨床判断の 一番の特徴と考える.

2 つ目の特徵として, クリティカルケア領域では対 象者との関わりが短いため, 判断の手がかりとして多 くの場面で以前の類似した経験を用いていることであ る. 精神科看護領域と同様に, クリティカルケア看護 師も患者の表情や視線, 行動といった患者の示す言動 を手がかりに臨床判断を行うが, 患者の情報が非常に 少ないため, 状況の変化を判断する際に, その患者と の関係性や以前との比較から判断するのでなく, 類似 した経験を活用し判断する比率が高くなる. 危機を早 期に判断するには，早い時点で警告を発している小さ な変化の重要性に気づき, その意味するものを理解す ることが重要だが, それには過去の類似体験が役に立 つ23. したがって, その状況についてどの程度経験し たことがあるかによって, 対象者への関心や懸念の程 度も変わってくる. ただし経験に基づく直観は言語化 しにくいため,「ただなら好予感」通常とは違うとい う感覚」というような言葉で表現されていると思われ る.

3つ目に, クリティカルケア看護領域では多職種と の協働によるチーム医療が不可欠であり, 医師を始め, 他の医療スタッフ間でのコミュニケーションによる情 報の共有をもとに臨床判断を行っているという特徵が ある. そのため臨床判断には他職種からの影響を受け ている. 特に医師との関係性は大きな影響要因となっ ていた.クリティカルケア看護領域では, 呼吸・循環 管理，鎮痛・鎮静に関連した薬剤投与などは医師によ る包括指示が多いため, 患者の状況をアセスメントし て実施を判断する場面が多い.さらに生命の危機状態 というクリティカルな状況下では, 患者や家族だけで なく医療者も緊張状態にあることで, 職種間のコミュ ニケーション, とりわけ医師との関係性が判断に影響 を及ぼしていると推測される. その他に病棟の方針や 忙しさがケアの実施の判断やそのタイミングに影響を 及ぼしている。 その一方で, 看護師の役割意識が, 忙 しい中でも必要なケアであれば実施しようと判断させ ていた. 臨床判断は, 状況が生じるコンテキストおよ び看護単位の文化によって影響を受ける ${ }^{25)}$ といわれて いるが, このような臨床判断への影響要因を查定し調 整することが, 臨床判断の内容や判断能力の育成に大 きな影響を及ぼすと考える。 


\section{2. 臨床判断能力育成のための方略への示唆}

臨床判断は，理論的知識と実践的知識に基づいて患 者の状況を把握し，分析的過程と直観的過程の両方を 用いて行われる. 患者の総合的なアセスメントや複数 の選択肢の中から意図的に選択し判断する力は，患者 の変化にすぐ対応することが求められるクリティカル ケア看護師には重要な技能であり, 理論的知識に基づ く分析的判断は最も早く身につけなければならない能 力とみなされている. そのために，新人看護師は集中 的な知識の注入や繰り返しの訓練という学習によって 状況を把握するための観察力とアセスメントカを高 め，臨床判断能力を獲得していく．臨床における最近 のシミュレーション教育もその一つである。一方，直 観は臨床状況の即時的な評価であり，同様の状況での 経験が持つ機能である ${ }^{24)}$. しかもクリティカルケア看 護領域においては，これまでの経験を想起し，目の前 の患者が示す反応を解釈し判断する比重が高いという 特徵がみられるため，体験的学習を経験知として実践 的な知識に置き換え蓄積していく必要がある. Tanner は，臨床判断に関する英語論文をもとに臨床判断のモ デルを開発し，モデルの教育的活用を述べている ${ }^{25)}$.

このモデルには, Noticing, Interpreting, Responding, Reflecting の 4 つの局面がある. その中で, Reflection-in-action( 行動しながら振り返る) と Reflection-on-action and Clinical Learning(行動後の振 り返りと臨床での学び) を重要な構成要素としている。 これは，本研究における 4 つの局面の〈振り返り，経 験の蓄えとする局面〉にあたり，この局面が他の 3 つ の局面と互いに関連していることからも臨床判断能力 を育むうえで重要な局面といえる，そのためには，あ る事例・場面を特定のものとして解釈し，語ることで 臨床判断の内容を言語化し，検討することが必要であ る.したがって，そのための振り返りをどのように実 践するかが, 看護師の臨床判断能力の育成のための今 後の課題である.

多くの思考錯誤や先輩看護師からの助言によって, その場の状況を論理的に整理し，質の良い経験にして いくためには，意図的に振り返る時間を設ける必要が ある，しかし，場面が次々と目まぐるしく変わり，忙 しいクリティカルケア看護領域の場で振り返りの場や 時間を確保することはたやすいことではない，坂口 $ら^{12)}$ の研究では, 臨床判断トレーニングシート用いて の事例の振り返りと事例カンファレンスによる自由な
語りが，これまで暗黙知とされていた知識を形式知に 置き換え, 知識の伝授を可能にすると報告されている. また, 忙しい中でのカンファレンスの開催においては, 1 事例 15 分 30 分以内とし，実施時間帯も状況に応 じて設定されたことが示されている．このような柔軟 性のあるカンファレンスの積み重ねが，経験知の積み 重ねにつながる.

また，成功体験がその後の臨床判断に大きな影響を 及ぼすといわれているが，クリティカルケア看護領域 では，患者の急変や対応の失敗なども貴重な経験とな る.ただし，起こった現象を客観的にとらえ，次につ ないでいくためには, 悲観的・否定的な感情を持ち越 さないことが重要である．特に経験の浅い看護師は， 失敗体験がトラウマにならないように適切で支持的な 助言を受けながら, 臨床での学びを振り返ることが重 要となる.

\section{3. 研究の限界と課題}

今回の研究の分析対象となったのが 8 文献とまだ数 が少なく, クリティカルケア看護師の臨床判断の特徴 を一般化するには限界がある。また，臨床現場も日々 変化しているため, 今後も研究を重ね, クリティカル ケア看護領域における臨床判断の特徵を精選し, 継続 的な検討を重ねていくことが今後の課題である.さら に対象文献が少なかったため, 本研究ではクリティカ ルケア看護領域として救急看護，ICU 看護，周手術期 看護を包括して分析したが，それぞれにおける共通性 と個別性があるので，今後はそれぞれの分野での検討 も必要と考える。

\section{VI. 結論}

1. 我が国におけるクリティカルケア看護領域におけ る看護師の臨床判断に関する研究は 2005 年以降 からみられ，2012 年 4 月までに発表された 8 文 献について分析した. 8 件の研究のうち 7 件が質 的研究で, 1 件がアクションリサーチであった.

2. 臨床判断の局面として，(1)見通しを立てる局面， (2)見通しを確定し，ケアを選択する局面，(3)ケア を実施しながら判断する局面，(4)振り返り，経験 の蓄えとする局面の 4 つの局面が見出された。さ らに臨床判断を構成している要素は, (1)臨床判断 
の内容に関するもの, (2)臨床判断に用いる情報, 手がかりに関するもの, (3)臨床判断に影響を及ぼ す要因に関するものの 3 つに分類された.

3. 患者との関係性を構築する時間が短いクリティカ ルケア領域では, 患者との関係性よりも, 最初の 印象と予測が大きな位置を占めるため, 疾患, 生 体情報, さらに疼痛などの症状とそれらの経時的 変化という客観的情報を用いた臨床判断が重要視 される. さらにその対象者から得られる情報が少 ないため, それに代わる手がかりとして, 過去の 類似した経験を用いる傾向にある。

\section{文献}

1) Benner P, Hooper-Kyriakidis P, Stannard D. 井上智子監訳. ベナー看護ケアの臨床知行動しつつ考えること. 東京 : 医学 書院；2005.

2) Sheila A Corcoran. 看護における Clinical Judgement の基本概 念. 看護研究. $1990 ； 23(4): 351-360$.

3) Christina A Tanner. 和泉成子訳. 看護実践における Clinical Judgement. インターナショナルナーシングレビュー. $2000 ; 23(4): 66-77$.

4) 飯塚麻紀, 鴨田玲子. 臨床判断研究の文献レビュー(1998 年 $\sim 2007$ 年). 福島県立医科大学看護学部紀要. $2010 ; 12$ ： 31-42.

5) 藤内美保, 宮腰由紀子. 看護師の臨床判断に関する文献的研 究一臨床判断の要素及び熟練度の特徴一. 日本職業 - 災害医 学会会誌. $2005 ； 53(4) ： 213-219$.

6) 飯塚麻紀. 開腹術後患者の早期離床ケア場面における看護師 の臨床判断.ヒューマンケア研究. $2011 ； 12(1) ：$ 9-21.

7) 飯塚麻紀, 鴨田玲子, 渡辺陽子他. 周手術期患者に対する病 棟看護師の臨床判断. 福島県立医科大学看護学部紀要. $2011: 13: 1-10$.

8) 村田洋章, 井上智子. 急性呼吸不全患者への非侵襲的陽圧換 気療法(NPPV) 継続のための看護師の臨床判断に関する研 究. 日本クリティカルケア看護学会誌. $2011 ； 7(1) ： 36-44$.

9) 黒岩郁子, 森下利子. 心臓手術患者の看護における臨床判断.
高知女子大学看護学会誌. $2009 ； 34(1) ： 44-52$

10）坂口桃子, 作田裕美, 佐藤美幸他. 臨床判断能力の向上に向 けた「暗黙知」伝授の一方略. 滋賀医科大学看護学ジャーナル. 2007 ; 5(1) : 38-42.

11）山崎加代子，酒井明子，高原美樹子他. 看護師の緊急性の判 断に関する研究 一初期 三次対応の救急外来において一. 日本救急看護学会雑誌. $2006 ； 7(2) ： 7-16$.

12）岩田幸枝, 國清恭子, 千明政好他. 異常を判断した ICU 看 護師の思考パターンの分析. 群馬保健学紀要. $2005 ; 26$ ： $11-18$.

13）杉本厚子, 堀越政孝, 高橋真紀子他. 異常を察知した看護師 の臨床判断の分析. 北関東医学. $2005 ; 55: 123-131$.

14）佐藤紀子. 看護婦の臨床判断の「構成要素と段階」と院内教育 への提言. 看護. $1989 ； 41(4): 127-143$.

15) Christina A Tanner. 堀内成子訳. クリニカル・ジャッジメン 卜の教育一文献検索一。看護研究. $1990 ； 23(4) ： 466-479$.

16） Patricia Benner. 早野真佐子訳. 達人の技を言葉にすること の意味. Nursing Today. 2002；17(12) : 8-12.

17) Patricia Benner. 井部俊子監訳, ベナー看護論 達人ナース の卓越性とパワー, 東京 : 医学書院；1992.

18）福田亜紀. 行動制限の場面における看護師の臨床判断の特徵. 日本精神保健看護学会誌. $2008 ； 17(1) ： 53-61$.

19）馬場香織. 精神科急性期病棟における暴力の危険性の察知と 看護師の臨床判断. 日本精神保健看護学会誌. $2007 ； 16(1)$ ： $12-22$.

20）坂江千寿子, 佐藤寧子, 石崎智子他. 精神科看護師のクリニ カルジャッジメント. 北海道医療大学看護福祉学部学会誌. 2006 ; 2(1) : 115-124.

21）安永薰梨．精神科閉鎖病棟において患者から看護師への暴力 が起こった状況と臨床判断. 福岡県立大学看護学部紀要. $2005 ; 3: 11-20$.

22）坂江千寿子，佐藤寧子，石崎智子他 . 保護室入室患者の開放 要求に関する精神科看護師のクリニカルジャッジメント．青 森県立保健大学雑誌. $2004 ; 6(2): 9-18$.

23) 前提書 1 )

24) Christina A Tanner，和泉成子訳，看護実践における Clinical Judgement. インターナショナルナーシングレビュー. $2000 ; 23(4): 66-77$

25) Christina A Tanner. Thinking Like a Nurse : A Research Based Model of Clinical Judgment in Nursing. Journal of Nursing Education. 2006 ; 45(6) : 204-211. 